\title{
Correction to: Updates in Genetic Testing Guidelines for Breast Cancer Susceptibility Genes: a Change in the Paradigm
}

\author{
Lorena Gonzalez $^{1} \cdot$ Laura Kruper $^{1}$
}

Published online: 17 July 2021

(C) The Author(s) 2021

\section{Correction to: Current Breast Cancer Reports (2019) 11:358-364 https://doi.org/10.1007/s12609-019-00339-x}

The article "Updates in Genetic Testing Guidelines for Breast Cancer Susceptibility Genes: a Change in the Paradigm", written by Gonzalez, L. and Kruper, L., was originally published Online First without Open Access. After publication in volume 11, issue 4, pages 358-364 the author decided to opt for Open Choice and to make the article an Open Access publication. Therefore, the copyright of the article has been changed to (C) The Author(s) 2021 and the article is forthwith distributed under the terms of the Creative Commons Attribution 4.0 International License, which permits use, sharing, adaptation, distribution and reproduction in any medium or format, as long as you give appropriate credit to the original author(s) and the source, provide a link to the Creative Commons license, and indicate if changes were made. The images or other third party material in this article are included in the article's Creative Commons license, unless indicated otherwise in a credit line to the material. If material is not included in the article's Creative Commons license and your intended use is not permitted by statutory regulation or exceeds the permitted use, you will need to obtain permission directly from the copyright holder. To view a copy of this license, visit http://creativecommons.org/licenses/by/4.0/.

The original article has been corrected.

Open Access This article is licensed under a Creative Commons Attribution 4.0 International License, which permits use, sharing, adaptation, distribution and reproduction in any medium or format, as long as you give appropriate credit to the original author(s) and the source, provide a link to the Creative Commons license, and indicate if changes were made. The images or other third party material in this article are included in the article's Creative Commons license, unless indicated otherwise in a credit line to the material. If material is not included in the article's Creative Commons license and your intended use is not permitted by statutory regulation or exceeds the permitted use, you will need to obtain permission directly from the copyright holder. To view a copy of this license, visit http://creativecommons.org/licenses/by/4.0/.

Publisher's Note Springer Nature remains neutral with regard to jurisdictional claims in published maps and institutional affiliations.

The online version of the original article can be found at https://doi.org/ 10.1007/s12609-019-00339-x

Laura Kruper

LKruper@coh.org

1 Department of Surgery, Breast Surgery Division, City of Hope National Medical Center Duarte, 1500 Duarte Rd,

Duarte, CA 91010, USA 